\title{
EVALUASI KEBIJAKAN TATA KELOLA HIPPAM OLEH BADAN USAHA MILIK DESA DEWAREJO UNTUK KESEJAHTERAAN MASYARAKAT
}

\author{
Silfa Ari Pradana, Slamet Muchsin, Hayat
}

Universitas Islam Malang (UINISMA) Jawa Timur, Indonesia

Email: silfaaripradana@gmail.com, s_muchsin63@unisma.ac.id, hayat@unisma.ac.id

\begin{abstract}
INFO ARTIKEL ABSTRAK
Diterima Mengetahui tentang Evaluasi Kebijakan Tata Kelola Hippam Oleh Badan 12 Oktober $2021 \quad$ Usaha Milik Desa Dewarejo Untuk Kesejahteraan Masyarakat: Terdapat 6

Direvisi

19 Oktober 2021

Disetujui

28 November 2021

Kata Kunci:

Evaluasi,

Kebijakan, faktor untuk mengukur tingkat efektivitas usaha yaitu: kooperatif, partisipatif, emansipatif, transparan, akuntabel, dan sustainabel. Hippam Selorejo dinilai dari prinsip kooperatif bahwa BUMDes Hippam telah menerapkan prinsip kooperatif. Hal ini dinilai karena adanya perbaikan dari sisi organisasi untuk perbaikan pengelolaan BUMDes Hippam. Segi partisipatif dan emansipatif bahwa prinsip partisipatif sudah dilaksanakan

BUMDes, Hippam baik dari masyarakat maupun petugas. Namun untuk petugas BUMDes Hippam belum secara maksimal. Adapun manfaat ekonomi yang dirasakan karena tarif Hippam yang sama setiap penggunaan dan murah. Manfaat sosial yang didapat yaitu bahwa Hippam Selorejo berorientasi sosial dan hal tersebut dinyatakan tercapai karena terbukti adanya subsidi silang yang diberikan kepada masyarakat.Manfaat budaya dan kerukunan bahwa dengan adanya Hippam Selorejo ini masyarakat semakin terjaga kerukunannya, karena adanya Hippam ini semakin membuat masyarakat lebih toleransi dan gotong-royong. Sedangkan manfaat lain yang dirasakan yaitu air yang mudah diakses masyarakat. Sebelum adanya Hippam akses air sulit. Sekarang bahkan air melimpah hingga dapat digunakan sebagai pengairan lahan masyarakat.
\end{abstract}

\section{ABSTRACT}

The results of the research in this writing, Knowing about the Evaluation of Hippam Governance Policies by Dewarejo Village Owned Enterprises for Community Welfare: There are 6 factors to measure the level of business effectiveness, namely: cooperative, participatory, emancipatory, transparent, accountable, and sustainable. Hippam Selorejo was judged on the cooperative principle that Hippam BUMDes had applied the cooperative principle. This is assessed because of improvements from the organizational side to improve the management of BUMDes Hippam. From the participatory and emancipatory aspects, the participatory principle has been implemented by both the community and officials. However, for BUMDes Hippam officers, it is not optimal. As for the perceived economic benefits because Hippam rates are the same for every use and are cheap. The social benefits obtained are that Hippam Selorejo is socially oriented and this is stated to be achieved because it is proven Keywords: $\quad$ that there are cross subsidies given to the community. mutual cooperation. Evaluation, Meanwhile, another perceived benefit is that water is easily accessible to Policy, BUMDes, the public. Before Hippam, access to water was difficult. Now even the Hippam. water is abundant so that it can be used as community land irrigation.

$\begin{array}{ll}\text { How to cite: } & \text { Silfa Ari Pradana. (2021). Evaluasi Kebijakan Tata Kelola HIPPAM Oleh Badan Usaha Milik Desa } \\ & \text { Dewarejo Untuk Kesejahteraan Masyarakat, Action Research Literate, 5(2). } \\ \text { E-ISSN: } & 2808-6988 \\ \text { Published by: } & \text { Ridwan Institute }\end{array}$




\section{Pendahuluan}

Dalam Peraturan Bupati Malang Nomor 27 Tahun 2020 Tentang Rencana Induk Sistem Penyediaan Air Minum Kabupaten Malang Tahun 2020 - 2040, Untuk memenuhi kebutuhan air minum sehari-hari masyarakat Kabupaten Malang memperoleh air dari berbagai sumber baik dengan menggunakan sistem perpipaan maupun sistem non perpipaan (Hidayati, 2017). Sarana air bersih dengan sistem perpipaan diperoleh dari Perumda Tirta Kanjuruhan yang merupakan perusahaan milik daerah, dan swadaya masyarakat melalui kelompok Hippam (Himpunan Penduduk Pemakai Air Minum). Dengan Hadirnya Hippam pemerintah sangat membantu untuk memenuhi kebetuhan masyarakat yang memiliki kendala atau kekurang dalam mendapatkan air. Dengan demikian kesejahteraan dapat dirasakan oleh masyarakat yang mebutuhkan Air, Kesejahteraan merupakan sejumlah kepuasan yang diperoleh seseorang dari hasil mengkonsumsi pendapatan yang diterima. Namun demikian yang dirasakan dari kesejahteraan itu sendiri merupakan sesuatu yang bersifat mengayomi karena tergantung dari apa diberikan atau yang diperoleh dari hasil mengkonsumsi pendapatan tersebut. Menurut (Sunarti, 2012) "Kesejahteraan adalah suatu tata kehidupan dan penghidupan sosial, material, maupun spiritual yang diliputi rasa keselamatan, kesusilaan dan ketentraman lahir batin yang memungkinkan setiap warga negara untuk mengadakan usaha-usaha pemenuhan kebutuhan jasmani, rohani dan sosial yang sebaik-baiknya bagi diri, rumah tangga serta masyarakat" dengan demikian kesejahteraan dapat di mengerti dengan mudah yaitu ketenangan lahir dan batin. Dengan adanya kesejahteraan yang dimana pemerintah berperan penting dalam memberikan pelayanan publik yang baik dan benar untuk mensejahterakan seluruh masyarakat. Adapaun pelayanan publik yang dimana Menurut (Hayat, 2017) 'Fokus utama kebijakan publik dalam negara modern adalah, pelayan publik, yang merupakan segala sesuatu yang bisa dilakukan oleh negara untuk mempertahankan atau meningkatkan kualitas kehiduapan orang banyak". Dengan dijelakan maksud dari kebijakan publik tersebut pemerintah sangat berperan penting untuk memperhatikan kualitas hidup seluruh masyarakatnya agar lebih baik, dengan adanya kebijakan publik masyarakat tidak khawatir lagi dalam mendapatkan pelayan, karena pemerintah hadir yaitu untuk melayani kebutuhan masyarakat, sehingga pelayan tersebut dibuat sedemikian rupa untuk menjamin kenyaman masyarakat (Afiyanti, 2010). Kebijakan publik juga merupakan tindakan-tindakan yang dilakukan oleh pemerintah untuk mengatur tata kelola kebijakan yang tindakan untuk memfasilitasi kebutuhan publik ataupun kebutuhan masyarakat, dengan demikian kebijakan publik bisa dikatakan berjalan ketika bisa memberikan kebijakan yang baik dan benar kepada masyarakat sesuai dengan peraturan ataupun sesuai dengan undang-undang yang berlaku. Dengan demikian pemerintah pusat mengeluarkan Undang-Undang, Pada Pasal 17, Undang-Undang No 17 Tahun 2019 menyebutkan Pemerintah desa atau yang disebut dengan BUMDes, memiliki tugas meliputi (Ridlwan, 2014) a. membantu Pemerintah Pusat dan/ atau Pemerintah Daerah dalam mengelola Sumber Daya Air di wilayah desa berdasarkan asas kemanfaatan umum dan dengan memperhatikan kepentingan desa lain, b. mendorong prakarsa dan partisipasi masyarakat desa dalam Pengelolaan Sumber Daya Air di wilayahnya, c. ikut serta dalam menjaga efektivitas, efisiensi, kualitas, dan ketertiban pelaksanaan Pengelolaan Sumber Daya Air, d. membantu Pemerintah Daerah kabupaten/kota dalam memenuhi kebutuhan pokok minimal seharihari atas Air bagi warga desa. 
Adapun Badan Usaha Milik desa (BUMDes) yang didefinisikan pada pasal 1 angka 6 UU No. 6 Tahun 2014 tentang Desa, Badan Usaha Milik desa selanjutnya di sebut Badan Usaha Milik Desa, adalah badan usaha yang seluruh atau sebagian besar modalnya dimilki oleh Desa melalui suatu pernyataan secara langsung yang berasal dari kekayaan Desa yang dipisahkan guna mengelola asset, jasa pelayanan dan usaha lainnya untuk sebesar-besarnya untuk suatu kesejahteraan masyarakat Desa.

\section{Metode Penelitian}

Penelitian ini menggunakan jenis penelitian deskriptif dengan pendekatan kualitatif (Sugiyono, 2017). Metode deskriptif adalah metode yang digunakan untuk memecahkan permasalahan yang diselidiki oleh peneliti yang berada di Desa Selorejo Kecamatan Dau Kabupaten Malang, dengan cara menggambarkan atau melukiskan suatu keadaan atau obyek dengan kondisi yang terjadi sesuai dengan fakta-fakta yang tampak bagaimana adanya. Metode deskriptif ini bertujuan mengungkap fakta yang terjadi saat proses berjalan dan memberikan data dengan apa adanya. Selain itu metode deskriptif harus searah dengan rumusan masalah karena tujuan tujuan dari penelitian ini akan menjawab yang sebelumnya dikemukakan oleh rumusan maslah (Cresswell, 2017).

\section{Hasil dan Pembahasan}

A. Manfaat Hippam untuk Masyarakat

1. Segi Ekonomi

Berdasarkan hasil wawancara bersama masyarakat bahwa dibandingkan dengan produk pengelolaan air bersih dan listrik menggunakan Hippam BUMDes Selorejo jauh lebih murah. Hal tersebut karena tariff pembayaran flat atau sama setiap KK. Baik penggunaan dalam jumlah besar atau sedikit. Sebelum pengelolaan air di pegang oleh
BUMDes, kendala-kendala masih kurang dapat cepat tertangani. Namun, setelah dikelola BUMDes kendala yang dahulunya lama terkendali, jadi cepat terkendalinya.

Menurut (Utomo, 2017) Judul: evaluasi perda kabupaten bojonegoro no. 9 tahun 2010 tentang desa (studi Evaluasi kebijakan BUMDes di desa sugihwaras kecamatan kepohbaru kabupaten bojonegoro. BUMDes di Desa ini memiliki 4 unit usaha yaitu unit usaha air bersih (Hippam), unit usaha simpan pinjam, unit usaha rumah bayar listrik, dan unit usaha toko pertanian. Permasalahan yang terdapat pada BUMDes ini adalah BUMDes ini belum mampu mengoptimalkan pendapatannya dari keempat unit usaha tersebut. Dapat disimpulkan bahwa pemerintah desa tersebut belum tepat dalam pengelolaan BUMDes, sehingga masih ada yang kakurangan sehingga btidak optimal dalam membangun BUMDes secara tepat, sehingga masih ada kerugian yang di alami.

Menurut (SAFINATUNNAJAH et al., 2020) dengan Judul evaluasi pengelolaan badan usaha milik desa di desa bangun seranten kabupaten tebo provinsi jambi. Dalam penelitiannya mengemukakan dalam pelaksanaan memanajemen BUMDes Bangun Seranten Yang masih aktif adalah di bidang penjualan pupuk, mampu mensejahterakan masyarakat serta meningkatkan perekonomian masyarakat walaupun belum siknifikan.

Dalam (Nugraha \& Kismartini, 2019) Evaluasi penyelenggaraan badan usaha milik desa (BUMDes) Rejo mulyo, Desa gogik, Kecamatan Ungaran barat, Kabupaten Semarang dalam penelitiannya mengemukakan pengelolaan BUMDes yang dapat meningkatkan perekonomian 
masyarakat sekitar dengan adanaya pengelolaan wisata air terjun yang ada didesa Desa Gogik, dalam penyelenggaraan masih kurang maksimal.

2. Segi Sosial Msyarakat

Berdasarkan hasil wawancara bersama masyarakat bahwa BUMDes Hippam ini berorientasi dari segi sosial bukan berdasarkan profit oriented. Hal tersebut yang menjadi alasan tariff Hippam rendah atau terjangkau. Tentunya dengan adanya tariff yang rendah dapat memberikan manfaat dari segi sosialnya. Karena masyarakat sangat terbantu dengan adanya Hippam Selorejo ini.

3. Segi Budaya dan Lingkungan

Berdasarkan hasil wawancara dengan pihak masyarakat bahwa terdapat manfaat dari segi kerukunan, jika terdapat air tetangga yang mengalami gangguan. Masyarakat lain atau tetangga saling bergotong-royong memberikan bantuan atau menyalurkan airnya.

4. Manfaat Lain

Berdasarkan hasil wawancara dengan masyarakat bahwa manfaat lain yang dapat dirasakan masyarakat bahwa air Hippam ini dapat membantu irigasi pertanian masyarakat. Sebelum adanya Hippam terdapat kesulitan dalam pengambilan air, sekarang air dapat terdistribusi dengan baik ke rumah-rumah masyarakat.

\section{Kesimpulan}

BUMDes Hippam desa Selorejo memberikan manfaat pada masyarakat dari segi ekonomi, sosial, budaya dan kerukunan, serta manfaat lain. Adapun manfaat ekonomi yang dirasakan karena tarif Hippam yang sama setiap penggunaan dan murah. Manfaat sosial yang didapat yaitu bahwa Hippam Selorejo berorientasi sosial dan hal tersebut dinyatakan tercapai karena terbukti adanya subsidi silang yang diberikan kepada masyarakat.Manfaat budaya dan kerukunan bahwa dengan adanya Hippam Selorejo ini masyarakat semakin terjaga kerukunannya, karena adanya Hippam ini semakin membuat masyarakat lebih toleransi dan gotongroyong. Sedangkan manfaat lain yang dirasakan yaitu air yang mudah diakses masyarakat. Sebelum adanya Hippam akses air sulit. Sekarang bahkan air melimpah hingga dapat digunakan sebagai pengairan lahan masyarakat

\section{Bibliografi}

Afiyanti, Y. (2010). Analisis konsep kualitas hidup. Jurnal Keperawatan Indonesia, 13(2), 81-86.Google Scholar

Cresswell, J. W. (2017). Research Design: Pendekatan Kualitatif, Kuantitatif, dan Mixed (Edisi Ketiga). Pustaka Belajar. Google Scholar

Hayat, H. (2017). Peneguhan Reformasi Birokrasi melalui Penilaian Kinerja Pelayanan Publik. Jurnal Ilmu Sosial Dan Ilmu Politik, 20(2), 175-188. Google Scholar

Hidayati, D. (2017). Memudarnya nilai kearifan lokal masyarakat dalam pengelolaan sumber daya air. Jurnal Kependudukan Indonesia, 11(1), 39-48. Google Scholar

Nugraha, A., \& Kismartini, K. (2019). Evaluasi Penyelenggaraan Badan Usaha Milik Desa (Bumdes) Rejo Mulyo, Desa Gogik, Kecamatan Ungaran Barat Kabupaten Semarang. Dialogue: Jurnal Ilmu Administrasi Publik, 1(1), 43-56. Google Scholar

Ridlwan, Z. (2014). Urgensi BUMDes dalam Pembangunan Perekonomian Desa. Fiat Justicia Jurnal Ilmu Hukum Fakultas Hukum Universitas Lampung, 8(3), 424-440. Google Scholar 
Safinatunnajah, S., Lestiyani, T. E. K., \& Prasaja, A. S. (2020). Evaluasi Pengelolaan Badan Usaha Milik Desa Di Desa Bangun Seranten Kabupaten Tebo Provinsi Jambi. UIN Sulthan Thaha Saifuddin Jambi. Google Scholar

Sugiyono. (2017). Metode Penelitian Kuantitatif, Kualitatif, dan $R \& D$. Alfabeta. Google Scholar

Sunarti, E. (2012). Tekanan ekonomi dan kesejahteraan objektif keluarga di perdesaan dan perkotaan. Retrived from

Http://Repository. Ipb. Ac. Id/Handle/123456789/72280. Google Scholar

Utomo, B. (2017). Evaluasi Perda Kabupaten Bojonegoro No. 9 Tahun 2010 Tentang Desa (Studi Evaluasi Kebijakan Bumdes Di Desa Sugihwaras Kecamatan Kepohbaru Kabupaten Bojonegoro. Publika, 5(3). Google Scholar

\section{Copyright holder :}

Silfa Ari Pradana (2021).

First publication right :

Action Research Literate

This article is licensed under:

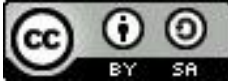

